\title{
Relação terapêutica e mudança de personalidade
}

\author{
Carlene Maria Dias Tenório ${ }^{l}$
}

RESUMO - Neste trabalho a questão da mudança de personalidade no processo terapêutico é discutida a partir de uma reflexão sobre o narcisismo. Nessa discussão, as idéias referentes ao narcisismo, amor, espelho, estranho, duplo e ego ideal são relacionadas entre si e com a relação terapêutica, tendo como base alguns textos de Freud, Guimarães Rosa e Rubem Alves.

Palavras-chave: Relação terapêutica, narcisismo, mudança de personalidade.

\section{Therapeutic relationship and personality change}

\begin{abstract}
In this paper, the issue about personality change during the therapeutic process is analyzes having the narcissism as a staring point of reflection. In this discussion, the ideas concerming narcissism, such as love, mirror, stranger, double and ideal ego are related to each other and to the therapeutic relationship, having some texts of Freud, Guimarães Rosa and Rubem Alves as references.
\end{abstract}

Key words: therapeutic relationship, narcissism, personality change.

Segundo a mitologia, (Brunnel, 1997) Narciso morre bem jovem sem conhecer o amor pelo outro. Morre quando conhece e ama a si mesmo. Sua morte foi um castigo da Deusa Nêmesis por ter se recusado a amar alguém.

Freud em Sobre o narcisismo: uma introdução diz que:

Um egoísmo forte constitui uma proteção contra o adoecer, mas, num último recurso devemos começar a amar afim de não adoecermos, e estamos destinados a cair doentes se, em conseqüência da frustração, formos incapazes de amar. (1914, vol. XIV p. 92).

1 Gestalt Terapeuta; Mestre e Doutoranda em Psicologia Clínica pela Universidade de Brasília-UnB; exprofessora da Universidade de Fortaleza-UNIFOR; professora doCentro Universitário de Brasília-UniCEUB; membro efetivo da diretoria e do corpo docente do Instituto de Gestalt Terapia de Brasília-IGTB. 


\section{Carlene Tenório}

Se o processo terapêutico pretende produzir mudanças na personalidade do indivíduo, por meio das quais pode ocorrer a cura, uma dessas mudanças deve ser a passagem de um amor narcísico para um amor objetal, ou seja, a transferência de uma parte da libido investida no ego para os objetos.

É importante lembrar que, em geral, a pessoa que busca terapia, inicialmente demonstra uma profunda insatisfação e inaceitação com relação a si mesma e uma profunda dependência e necessidade de valorização por parte dos outros. Neste sentido, poderíamos, então, dizer que o neurótico não ama a si mesmo, mas apenas o outro? Sua libido está totalmente investida em seus objetos e não em si mesmo? Desse modo, seria contraditório dizer que o amor objetal é a saída para a cura? Essas questões são bem complexas e suas respostas exigem uma análise mais aprofundada.

O neurótico é, no fundo, uma criança que nunca se sentiu verdadeiramente amada ou aceita por seus pais, ou seja, o amor e aceitação experimentados sempre foram condicionados à realização das expectativas idealizadas por parte destes. Os pais do neurótico esperam que este seja tudo que eles idealizaram ser. Do mesmo modo que esses pais têm expectativas idealizadas com relação a si mesmos, têm também com relação a seus filhos. Como, na maioria das vezes, eles não conseguiram satisfazer essas idealizações referentes a si mesmos, torna-se imprescindível que essas mesmas idealizações sejam, finalmente, cumpridas por seus próprios filhos. Neste sentido, esses pais nunca se amaram verdadeiramente, nem a seus filhos. Nestas circunstâncias, a criança precisa satisfazer as expectativas de seus pais para poder se sentir amada e, a partir da internalização dessas expectativas, ela constrói uma imagem idealizada de si mesma, que passa a funcionar como um supereu que fiscaliza e impõe normas a sua própria maneira de ser, condicionando sua valorização e auto-estima ao cumprimento dessas normas.

Portanto, à medida que o neurótico corresponde às exigências impostas pelo supereu, ele se ama e se valoriza, ao mesmo tempo em que não corre o risco de ser rejeitado ou desvalorizado pelo outro, já que isto poderia abalar profundamente sua auto-estima.

Na verdade, a única coisa que o neurótico consegue amar é sua própria imagem idealizada. Tudo aquilo que se mostra diferente disso, tanto em si mesmo como no outro, é rejeitado. É como se ele tivesse substituído o amor pelo outro pelo amor dirigido ao eu ideal, ou seja, trocou o amor objetal pelo amor narcísico. $\mathrm{Na}$ neurose, tudo que corresponde a essa imagem idealizada de si mesmo é considerado bom, belo, amado, valorizado e familiar, ou seja, é reconhecido e aceito como sendo parte de si mesmo. Por outro lado, tudo que não corresponde a essa imagem é considerado mau, feio, rejeitado, desvalorizado e estranho, isto é, não é reconhecido como parte de si mesmo, é negado ou reprimido. 
Se considerarmos tudo que se diferencia do eu, enquanto imagem aceita ou idealizada de si mesmo, como sendo o outro, podemos dizer que é a capacidade para amar o diferente, ou seja, é o amor objetal e não o amor narcísico que pode gerar saúde, mesmo que esse outro, estranho e desconhecido, habite seu próprio mundo interior ou represente aspectos de si mesmo até então desconhecidos ou reprimidos.

A incapacidade para amar o outro e a grande capacidade para amar apenas a si mesmo foram a causa da morte de Narciso. Com base nesse mito, podemos reafirmar que o amor objetal é a saída para uma mudança que vai gerar a cura.

Freud (1914) confirma essa hipótese quando esclarece:

"Descobrimos, de modo especialmente claro, em pessoas cujo desenvolvimento libidinal sofreu alguma perturbação, tais como pervertidos e homossexuais, que em sua escolha ulterior dos objetos amorosos elas adotaram como modelo não sua mãe, mas seus próprios eus. Procuraram inequivocamente a si mesmas como um objeto amoroso, e exibem um tipo de escolha objetal que deve ser denominada narcisista”. (vol. XIV pág. 94).

Pensando mais sobre o mito, é pertinente questionar: Narciso amou a si mesmo ou apenas sua bela imagem refletida no espelho das águas?

Em princípio, o espelho reflete uma imagem, não revela o que eu sou, mas apenas aquilo que aparento ser. No entanto, é através do espelho que eu me vejo, que eu me conheço. Mas será que o que eu vejo no espelho sou eu mesmo? Será que o espelho me revela com fidelidade aquilo que sou? Por outro lado, será que eu consigo ver tudo que o espelho me mostra? Ou será que eu só vejo aquilo que me convém, aquilo que posso ver ou que gosto de ver?

Aqui está o problema: às vezes é difícil olhar-se no espelho, às vezes o que eu vejo me parece estranho, não parece ser eu mesmo, a imagem refletida, embora seja conhecida, tem algo que me incomoda, me inquieta, me assusta! Fazendo uma analogia entre o espelho e a terapia, não poderíamos dizer que fazer terapia não seria, em última instância, um olhar-se no espelho? E desse modo, a voz do terapeuta, não seria o espelho que vai refletir a imagem do que sou ou daquilo que aparento ser?

Nesse caso, é a fala do cliente que vai dar forma à imagem de si mesmo que, uma vez captada pela escuta do terapeuta, é devolvida para ele. No entanto, esse é o ponto principal: essa imagem que é devolvida pelo terapeuta nem sempre é uma imagem conhecida ou aceita pelo cliente, às vezes ela lhe parece estranha e assustadora. 
Guimarães Rosa (1988), no conto O Espelho, nos descreve:

Fui num lavatório de edifício público, por acaso. Eu era moço, comigo contente, vaidoso. Descuidado, avistei... Explico-lhe: dois espelhos - um de parede, o outro de porta lateral, aberta em ângulo propício - faziam jogo. E o que enxerguei, por instante, foi uma figura, perfil humano, desagradável ao derradeiro grau, repulsivo senão hediondo. Deu-me náusea, aquele homem, causava-me ódio e susto, eriçamento, espavor. E era - logo descobri... era eu, mesmo! O senhor acha que eu algum dia ia esquecer essa revelação? (pág. 439).

Refletindo um pouco sobre este trecho do conto de Guimarães Rosa e ainda fazendo um paralelo com o processo terapêutico, não seria o diálogo entre o terapeuta e seu cliente um jogo interativo de duas falas, de duas imagens, de dois sentidos que, colocado um diante do outro, a partir de um determinado ângulo que seria a teoria sobre a psicodinâmica da personalidade - iria produzir, revelar uma terceira imagem, uma imagem nova e diferente, tanto daquela vista pelo terapeuta num primeiro momento, como daquela já conhecida pelo cliente?

Neste sentido, seria essa nova imagem que causaria surpresa ou estranheza ao cliente. Mas, o que é interessante observar é que essa terceira imagem não é inteiramente nova ou diferente, ela é apenas a mesma imagem outrora conhecida que agora é vista de outra forma, por outro ângulo, ou seja, pelo ângulo que possibilita uma consciência mais ampla - uma iluminação mais forte - capaz de incluir e revelar aspectos obscuros, reprimidos, compondo assim uma nova forma, uma nova versão da mesma imagem.

A respeito do estranho, no sentido daquilo que é, ao mesmo tempo, velho e novo, conhecido e desconhecido, enquanto algo que antes estava morto e agora renasce, que antes estava escondido e agora reaparece, Freud (1919) comenta:

..., pois esse estranho não é nada novo ou alheio, porém algo que é familiar e há muito estabelecido na mente, e que somente se alienou desta através do processo da repressão. Essa referência ao fator da repressão permite-nos ademais, compreender a definição de Schelling [pág. 242] do estranho como algo que deveria ter permanecido oculto, mas veio à luz. (vol. XVII pág. 258).

Outro aspecto interessante referente à questão do espelho e da terapia é o aspecto da duplicidade que também se relaciona com o estranho. A pessoa que se vê diante do espelho, se vê diante do seu duplo, do mesmo modo quando se vê através da fala do terapeuta. No entanto, esse duplo - imagem de si mesma refletida 
pelo espelho ou pelo terapeuta - pode ser causador de ansiedade, pode ser visto como estranho e assustador.

Além da explicação de que a sensação de estranheza pode ser causada por aquilo que emerge da escuridão do inconsciente, Freud também explica que o estranho pode ser aquilo que se contrapõe ou que não corresponde ao modelo ideal de ego e que por isso é reprimido.

Neste sentido, toda pessoa constrói ao longo de sua vida, um duplo - uma imagem idealizada de si mesma - que corresponde, inicialmente, às exigências e às expectativas dos outros e, depois, de si mesma, mas que não corresponde à realidade própria de seu ego.

A idéia do 'duplo' não desaparece necessariamente ao passar o narcisismo primário, pois pode receber novo significado dos estádios posteriores do desenvolvimento do ego. Forma-se ali, lentamente, uma atividade especial, que consegue resistir ao resto do ego, que tenha função de observar e de criticar o eu (self) e de exercer uma censura dentro da mente, e da qual tomamos conhecimento como nossa 'consciência' (...) O fato de que existe uma atividade dessa natureza, pode tratar o resto do ego como um objeto isto é, o fato de que o homem é capaz de auto-observação - torna possível investir a velha idéia de duplo de um novo significado e atribuir-lhe uma série de coisas - sobretudo aquelas coisas que, para a autocrítica, parecem pertencer ao antigo narcisismo superado dos primeiros anos. (Freud, 1919 vol. XVII p. 253).

É esse modelo ideal de ego, ou esse duplo idealizado, juntamente com a capacidade da própria consciência de auto-observação e autocensura, que vai fazer com que aquilo que é revelado pelo espelho ou pela fala do terapeuta seja recusado e visto como estranho e assustador, uma vez que, por não corresponder à imagem idealizada e aceita de si mesmo, foi reprimido anteriormente e agora se revela como algo novo.

Guimarães Rosa (1988), ainda em seu conto O Espelho comenta:

Quem se olha em espelho, o faz partindo de preconceito afetivo, de um mais ou menos falaz pressuposto: ninguém se acha na verdade feio: quando muito, em certos momentos desgostamo-nos por provisoriamente discrepantes de um ideal estético já aceito. Sou claro? O que se busca, então é verificar, acertar, trabalhar um modelo subjetivo, preexistente; enfim juntos ampliar o ilusório, mediante sucessivas novas capas de ilusão (pág. 439).

Existe, portanto, um modelo preexistente de ego, já aceito por ser visto 
como belo e perfeito, que é alvo de todo meu amor e admiração. Quando o que eu vejo refletido no espelho, no terapeuta ou no outro é essa imagem de mim mesmo idealizada e bela, então eu me amo, amo o outro e estou em paz.

A respeito disso, Freud (1914) esclarece:

Esse ego ideal é agora o alvo do amor de si mesmo (self-love) desfrutado na infância pelo ego real. O narcisismo do indivíduo surge deslocado em direção a esse novo ego ideal, o qual com o ego infantil, se acha possuído de toda perfeição de valor (...) Ele não está disposto a renunciar à perfeição narcisista de sua infância; e quando, ao crescer, se vê perturbado pelas admoestações de terceiros e pelo despertar de seu próprio julgamento crítico, de modo a não poder reter aquela perfeição, procura recuperá-la sob a nova forma de um ego ideal. O que ele projeta diante de si como sendo seu ideal é o substituto do narcisismo perdido de sua infância na qual ele era seu próprio ideal. (vol. XIV pags. 100-101).

A construção desse ideal de ego, portanto, consiste numa forma de saída para não abdicar do amor narcísico.

Dificilmente amamos aquilo que é feio, ou que é estranho e assustador. Costumamos amar apenas aquilo que é belo, conhecido e familiar, como já dizia Freud: "O amor é a saudade de casa". Mas esse amor é aquele que adoece e que até pode levar à morte, à medida que se restringe ao próprio ego, quando não se dirige também para fora, para o outro, para aquilo que é diferente, desconhecido e estranho.

É preciso saber olhar, aceitar e amar também aquilo que é diferente, desconhecido, estranho, tanto em mim mesmo como no outro. Aliás, se eu tenho a capacidade para amar a mim mesmo, mesmo quando vejo em mim a feiúra e não a beleza, o estranho e não o familiar, então eu tenho também a capacidade para amar o outro, com tudo que ele tem de diferente, desconhecido, feio e estranho.

É importante, porém, fazer uma diferença entre o amor e a paixão. No amor eu vejo, aceito e amo o outro naquilo que ele tem de diferente, mesmo que me pareça feio e estranho. Na paixão, eu amo a minha imagem idealizada, projetada no outro. Eu aceito e amo a mim mesmo, à medida que vejo em mim o que é belo, perfeito, conhecido e aceitável, e amo o outro de paixão, quando vejo nesse outro toda a beleza e perfeição desejada para mim mesmo, que é projetada nele.

O estar apaixonado consiste num fluir na libido do ego em direção ao objeto. Tem o poder de remover as repressões e de reinstalar as perversões. Exalta o objeto sexual, transformando-o num ideal sexual. (...) O ideal sexual 
pode fazer parte de uma interessante relação auxiliar com o ideal do ego. Ele pode ser empregado para satisfação substitutiva onde a satisfação narcisista encontra reais entraves. Nesse caso, uma pessoa amará segundo o tipo narcisista de escolha objetal: amará o que foi outrora e não é mais, ou então o que possui as excelências que ela jamais teve. (Freud, 1914, vol. XIV pág. 107).

Desse modo, a paixão não é amor verdadeiro. No amor verdadeiro, o ego está fortalecido e possui uma dose suficiente de catexia. Nesse tipo de amor, o sujeito ama seu objeto independente da condição de ser ou não amado por este, uma vez que não existe, de forma dominante, a necessidade de ser amado pelo outro em primeiro lugar, como acontece no narcisismo e na neurose.

Na pessoa saudável, a necessidade predominante é de amar e não de ser amada, exatamente como acontece no modelo masculino de amor, como diz Freud (1914). Na neurose, a pessoa não pode abrir mão da necessidade narcísica de ser amada, já que seu ego se encontra enfraquecido e debilitado, devido a sucessivas investidas frustradas, nos objetos amorosos de sua infância. Na verdade, o neurótico nunca se sentiu verdadeiramente amado, mesmo quando correspondia ao modelo de ego desejado por seus pais. Diante dessa frustração em suas relações amorosas, sua única saída foi retirar a libido dos objetos e reinvesti-la em seu próprio ego. Sobre este assunto, Freud (1914) diz:

O amar em si, na medida em que envolva anelo e privação, reduz a autoestima, ao passo que ser amado, ser correspondido no amor, e possuir o objeto amado, eleva-a mais uma vez. Quando a libido é reprimida, sente-se a catexia erótica como grave esgotamento do ego; a satisfação do amor é impossível e o enriquecimento do ego só pode ser efetuado por uma retirada da libido de seus objetos. À volta da libido objetal ao ego e sua transformação no narcisismo representa, por assim dizer, um novo amor feliz. (Freud, 1914, vol. XIV pág. 106).

Rubem Alves (1994), em sua crônica A madrasta e o espelho comenta que todos nós estamos à procura de um espelho que nos diga sempre: "Tu és o mais belo!". Na verdade nós amamos as pessoas, não pela beleza que existe nelas, mas pela beleza nossa que nelas aparece refletida. Uma bela pessoa é aquela em que nos vemos belos. Quando ao contrário, o espelho encontrado nos mostra uma imagem feia, vai-se o amor e o espelho é quebrado ou colocado permanentemente num quarto de escuridão permanente. Não mais o queremos ver.

$\mathrm{Na}$ verdade, é isso que acontece quando a criança, de forma ingênua e espontânea, se mostra para o outro e é rigidamente criticada ou punida. Nesse momento é como se ela olhasse para o espelho e escutasse uma voz brava gritando: "Você 
é feia!”. Com base nessa experiência, aquilo que foi severamente criticado pelo outro, embora sendo relativo a seu próprio ego, é então reprimido.

Desse modo, para que a criança não perca de vez seu amor próprio, nem a esperança de poder ser amada pelo outro, ela passa a criar, para si mesma, um modelo de ego idealizado, que ela vai amar e, em sua fantasia, vai ser amado por aquele que a criticou. No entanto, essa estratégia de defesa acaba gerando outras dificuldades, como por exemplo: medo de se deparar com aquilo que foi reprimido, medo de encarar sua imagem real, incapacidade para aceitar o estranho no outro e em si mesma. Este é o ciclo da neurose que impede qualquer tipo de mudança e de crescimento.

É exatamente nesse ponto que existe a possibilidade de uma mudança em direção à cura: quando o neurótico consegue olhar-se no espelho, sem medo de se descobrir feio ou estranho; quando consegue escutar e aceitar a fala do terapeuta, mesmo quando esta the revela uma verdade nova sobre ele mesmo, uma autoimagem diferente daquela que ele já conhecia ou desejava e que, por isso, parece surpreendente e assustadora; finalmente, quando ele pode abrir mão de seu narcisismo e amar o outro independente de ser ou não amado por este, mesmo que este não seja como ele desejava que fosse.

\section{Referências bibliográficas}

ALVES, R. O Retorno Eterno. Crônicas, Campinas - SP: Ed. Papirus, 1994.

BRUNUEL, P. Dicionário de Mitos Literários. Brasília: Ed. UnB, 1997.

FREUD, S. Sobre o Narcisismo. Uma introdução, ESB, vol. XIV, 1914.

FREUD, S. O Estranho, ESB, vol. XVII, 1919.

ROSA, G. Primeiras estórias, Rio de Janeiro: Ed. Nova Fronteira, 1988. 